\title{
INSTITUTIONAL COMPLEMENTARITY FOR SOCIAL AND ECONOMIC DEVELOPMENT
}

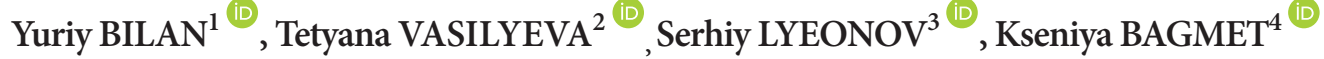 \\ ${ }^{1}$ Research Associate, Centre of Applied Economic Research, Faculty of Management and Economics, \\ Tomas Bata University in Zlin, Zlin, Czech Republic \\ ${ }^{2}$ Educational and Research institute of Finance, Economy and Management named Oleg Balatskiy, \\ Sumy State University, Sumy, Ukraine \\ ${ }^{3}$ Department of Finance, Banking and Insurance, Sumy State University, Sumy, Ukraine \\ ${ }^{4}$ Doctoral candidate, Sumy State University, Sumy, Ukraine \\ E-mails: 1yuriy_bilan@yahoo.co.uk; ${ }^{2}$ tavasilyeva@fem.sumdu.edu.ua (corresponding author); \\ ${ }^{3}$ s.lieonov@uabs.sumdu.edu.ua; ${ }^{4}$ kbagmet2017@gmail.com
}

Received 26 November 2018; accepted 28 January 2019

\begin{abstract}
Today the prevention of global challenges (from global security to the problems of poverty) relates to the institutional quality. Nowadays, the social standards or other "social rules" make the part of the market system, since they are built into the country's institutional structure. Neither social nor economic reforms can be implemented without the support through institutional mechanisms.

The purpose of this paper is to explore the relationship between social sector institutions and basic institutions, taking into account the economic development of countries and the way in which they are formed.

A number of empiric studies confirmed significant role of institutions to provide conditions for economic development. In order to define and assess the link between the basic institutions and the social sector institutions, we formed panel data that includes 20 countries for the period from 2007-2014. We assessed quality of the basic institutions using The Worldwide Governance Indicators (WGI). WGI methodology provides an evaluation of six dimensions of the institutional quality that enables to define the connection and the impact of every dimension on the institutional quality of the social sector.

The model additionally evaluates the impact of the incomes distribution inequality, general economic welfare on the institutional quality of the social sector. Among all dimensions of governance "Rule of Law" and "Regulatory Quality" the statistically significant direct impact on the institutional quality of the social sector has been revealed. It confirms the complementarity of basic institutions and institutions of the social sector.
\end{abstract}

Keywords: institutions, economic development, complementarity, institutional quality, social sector, dimensions of governance.

JEL Classification: D02, I31, O17.

\section{Introduction}

Today the sustainable development goals are on the agenda of the international community. Institutional changes can play significant role in their achievement. According to IMF estimates (IMF, 2005), GDP per capita of sub-Saharan Africa might be expected to rise about 85 percent if the institutional quality enhances to the level of developing Asia. Among SDGs the most are of the social nature. Thus, such goals as no hunger, poverty reduction, gender equity, welfare and health require the relevant institutions of the social sector.

The institutional quality in Ukraine is the issue regarding the ability for further progress. In 2017 Ukraine took the 81st place among 137 countries by the global competitiveness index. Currently, Ukraine has a 128th place in the protection of the property rights that may be considered as

Copyright $\odot 2019$ The Authors. Published by VGTU Press.

This is an Open Access article distributed under the terms of the Creative Commons Attribution License (http://creativecommons.org/licenses/by/4.0/), which permits unrestricted use, distribution, and reproduction in any medium, provided the original author and source are credited.. 
a low quality of the basic institutions, which form the institutional structure (WEF 2018). The negative factors to run business include corruption, political instability, the instability of governments, ineffective state bureaucracy, lack of workers' education, workers' bad ethics, insufficient ability to innovations, restrictive regulation of the labour market, inappropriate infrastructure quality, low health quality. The demonstrated evaluations prove that most problems relate to the institutions' quality in general and particularly to the problems of the social sector. That is why investigating the institutional quality problem we focus on the social aspects.

Formation of new institutions is a conscious attempt to improve social consequences, to create social welfare. However, the question appears: will the institutions function effectively? How they are implemented in the current institutional structure? We suppose that the answer to this question should be found in the institutions' complementarity. So, we will try to find out how institutions of the social sector and key dimensions of governance are interconnected, based on the proposed methodology to evaluate the institutional quality of the social sector (Vasilyeva et al. 2018a, Bagmet and Haponova 2018).

Literature review section provides the analysis of contemporary results of researches on institutional quality and complementarity of institutions. We use panel data analysis including Pooled OLS estimators, Fixed effects estimator and Random effects models in oder to prove our hypothesis. The chosen methodology and data is describe in relevant section. The "results" section contains the results of the calculations and their explanations. Conclusions section contains the conclusions of the study of their decline in the context of the results of other researches on this issue.

\section{Literature review}

While studying the institutional quality, we found several aspects, which the quality of institutions is associated with:

- the efficiency of institutions, their impact on economic growth;

- the regulatory role of institutions (institutions of regulation and their impact on the development);

- complementarity of institutions and institutional changes.

The institutions' efficiency, i.e. their impact on the economic growth or economic development, is the most actively studied topic in the context of the institutional quality. It is traditionally believed that the institutional quality and economic development strengthen each other in the long-term perspective. While studying the relationships between institutional quality and economic development, Bruinshoofd (2016) concluded that the institutional quality enables countries to achieve the long-term income convergence, since the high qualitaty institutions stimulate the economic progress through the creation of conditions which assist in the technological changes and innovations acceptance. Thus, he supposes that in the cooperation of two driving forces "economic development - institutional quality" the institutional quality is a starter mechanism, which increases this cooperation and forms preconditions for the structural development and long-term increase of the welfare.

Acemoglu D. Johnson S. Robinson J. A. (2005) argued that distinctions in economic institutions are the main cause of different models of economic growth. At the same time it is vital to protect property rights, provide equality in opportunities, safety.

The institutional quality impact on the economic growth, as a rule, is defined via peculiarities of the social and economic models of different countries, particularly, changes in the transition economies (Melnyk et al. 2018), Redek and Susjan (2005). Chousa et al. (2005), Vitola and Senfelde (2015) evaluated the institutional system's development in transition economies and the impact it has on economic performance. Using operational indicator of institutional system dynamics they proved dependence between institutional changes and economic growth in transition economies. The problems to improve the institutions and economies' functioning in the transition countries are studied by Efendica and Pugh (2015) and Efendica et al. (2010), Draskovi et al. (2017), Kyrychenko et al. (2018), Rivera Rios et al. (2018). Pilia (2017) proved in her work that the economic growth of the countries in the transition period depends on the chosen model of economic development. Harold et al. (2018) gave an example that according to the neoclassical growth theory, export expansion could stimulate economic growth because it promotes specialisation and raises factor productivity.

Studying the determinants of the institutional quality and their impact on the economic growth in the countries of Central and North-Eastern Africa, Kandil (2009) states that the institutional quality worsens with GDP growth per capita in these countries, a higher credit rating and higher openness degree improve the institutional quality.

Besides, the scientist in the paper "Environmental performance and institutions quality: evidence from developed and developing countries" that a high quality of institutions significantly enhance an environmental performance in developed countries (Dkhili 2018).

Valeriani and Peluso (2011) focus their attention on two aspects: 1) influence of the institutional quality on the economic growth, 2) dependence of the institutional quality influence on the countries' (institutions') development degree. According to their conclusions, the difference in institutions' impact on the developing and developed countries' economic development is that various constituents (indicators) of the institutional quality show a different degree of the influence on the economic growth for different countries. 
The recognition of the institutions' significant role to provide the social and economic development is confirmed by researches of their interconnection with other factors of development, particularly with social capital (Kaasa 2016), innovations (Kaasa et al. 2007). Hall (2015) showed that $\beta$-convergence in economic freedom occurred from 1980 to 2010. And besides, the structural characteristics that contribute to this institutional convergence are documented. The problem of the social development and institutions' role is studied by Harshad (2017a, 2017b). Iqbal (2018) states that the human development is an elemental part of the production and economic growth. Jayasundera (2017) shows the human development; a phenomenon that changes rapidly and a methodical study that helps to acquire knowledge and investigated the development of trade and economy in ancient Sri Lanka.

Thus, most empiric researches study the institutional quality in the interconnection with economic growth. In general, one can make a conclusion that the institutional quality relates to economic growth. As a rule, researchers make the general assumption that high institutional quality positively influences economic growth, i.e. the economic growth is observed as a variable which depends on the institutional quality. The institutional changes can be classified according to such characteristics as duration, resource constraints, direction of changes and number of stages (Shvindina 2017: 74-82). According to the study the leadership is a key component of transformation and it should be considered as a multifactor model.

In the context of regulation Kaufmann et al. (2010), Cavalcanti and Novo (2005) study relationships between regulating institutions and economic development. Particularly, they give the relevant evaluations for six governance constituents.

Kostel et al. (2017) states that institution play a great role in social, economic and political progress of the country. In 2016 meeting of the High-Level Political Forum (HLPF), mandated to follow up and review the implementation of the 2030 Agenda for Sustainable Development took place in New York. Several speakers noted that "institutions matter" - with some stating that strong, stable and mature institutions are crucial for the implementation of the SDGs (Kostel et al. 2017: 80).

As a rule, the institutions' convergence is studied with reference to the development of countries, which are at the stage of their social and economic models' transformations, particularly countries - candidates to the EU members (Bartlett et al. 2013). Hájek et al. (2016), Elert and Halvarsson (2012) investigate the institutional convergence between countries in the long-term perspective. Schönfelder and Wagner (2018) investigate the institutional convergence in Europe.

The institutional complementarity as the theoretical concept is used to explain the institutional changes, institutions' evolution (Boyer 2005, 2007, Amable 2016).
The institutional changes as factors of social and economic development are studied by (Draskovic et al. 2017). The macroeconomic stability issues and its institutional principles are investigated by (Vasilyeva et al. 2018b). Lunyakov et al. (2013) study the cyclic dynamics of the social and economic development and institutional changes, that accompany it. The study of Logan and Esmanov (2017) showed that the institutes of state financial control constantly undergo organizational changes, which, of course, affect the effectiveness of their functioning.

According to Rogowski (2017) concepts such as norms, organizations and institutions are needed in every economy to stabilize it.

Pagano (2011) studies historical peculiarities regarding the formation and development of institutions and explains the institutional changes through the institutional complementarity. In his opinion, the institutional complementarity study creates the base for effective transformation of institutions, enables to avoid the unexpected negative consequences.

The political and economic institutions' dependence is confirmed by studies of (Bartlett et al. 2013, Yevdokimov et al. 2018). The political institutions, particularly political stability, governmental accountability, responsibility chains, freedom of mass media and fighting corruption are important for configuration and functioning of the key economic institutions. Eicher and Schreiber (2010) make the "hypothesis of the institutional hierarchy", that defines the dependence of the economic institutions on the quality of the political institutions.

Tamilina L. and Tamilina N. $(2014,2017)$ explain the peculiarities of the institutions' influence on the post-soviet countries' growth through the nature of their origin - evolutionary or revolutionary. The difference between revolutionary and evolutionary processes to form institutions is a reason that post-socialist countries represent different dynamics of social and economic development. Their economy's growth rates less probably depend on the economic institutions' quality. At the same time, political institutions' maturity is a determining factor. Thus, the idea regarding institutions' hierarchy, where the basic level is presented by political institutions, is confirmed.

Boyer (2005) supposes that the institutions' complementarity hypothesis is the most appropriate to explain many factors in the economic policy, reforming in the post-socialist countries. However, the evaluation of complementarity is difficult, since the uncertainty and weakening of the relationship between different institutions require a combination of methodologies to reveal the complementarity.

Concluding this short review, allows to allocate the most essential features of the institutional complementarity:

1) It is reasonable to observe the institutional complementarity as a condition of the institutional changes' efficiency. Thus, the institutional changes, 
introduced with the aim to improve social welfare, have to be analyzed for the complementarity position.

2) It is difficult to form the universal approach to the institutional complementarity evaluation since it always relates to the concrete institutional structure. So, the complementarity dimensions of institutions are defined by the concrete tasks and study's context.

3) It is reasonable to study the complementarity in two planes: horizontal (compliance of institutions of one level) and vertical (compliance of the institutions from different countries with institutions of different levels within the institutional structure in the relevant country).

Our hypothesis is the complementarity of institutions affects the quality of institutions of the social sector, in other words, the quality of institutions of the social sector depends on the institutions of regulation. We will evaluate the regulating institutions based on the six dimensions governance ${ }^{1}$, which make World Governance Index.

In the process of the study, we face with the problem regarding the reduction of evaluations in the concrete institutions. Within the question about institutional quality dimensions choice, their representativeness, relevancy, there is a question: how do the narrowly focused assessments answer the question?

\section{Methodology and data}

In order to carry out the empiric analysis, we create a panel of data, which enables to combine many observations by different countries considering the variables dynamics in time. It increases the number of freedom degrees and reduces the standard mistakes of the obtained assessments. Besides, using the panel data we can analyse the impact of the countries' individual institutional features, which are constant in time.

Following the classical analysis, at the first step, we will conduct direct evaluation of our model equation (Pooled OLS estimator), which ignores the panel nature of the data. Then we will evaluate the regression with random individual effect (Random effects estimator). In the third step, we will construct the model with determined individual effect (Fixed effects or within estimator). We will compare these three models in order to understand which of them is more convenient for our data. Using the Breusch and Pagan Lagrangian multiplier test for random effects and Hausman test for fixed versus random effects model in the process of

\footnotetext{
Governance consists of the traditions and institutions by which authority in a country is exercised. This includes the process by which governments are selected, monitored and replaced; the capacity of the government to effectively formulate and implement sound policies; and the respect of citizens and the state for the institutions that govern economic and social interactions among them (Kaufmann et al. 2010).
}

models' comparison, we will select the model with the best quality of assessments. The models will be evaluated with the help of the program STATA 13.0.

The panel, which we will use for testing, includes data for 8 years during 2007-2014. We use indicators of 20 countries in the analysis. The following aspects are taken into account in the formation of the countries' list:

1) A direct connection between institutions and the countries' economic development. A lot of studies confirm that economically developed countries traditionally have stable and mature institutions. Acemoglu and Johnson (2005) determine that institutions' improvement by $1 \%$ provides the growth of the labour efficiency in average by $5 \%$.

2) The quality of relationships between institutions and economic growth also depends on the way how institutions are formed (evolutionary and revolutionary). Tamilina and Tamilina (2014) conclude that a positive impact of the economic institutions on the economic growth is higher, when such institutions are formed in an evolutionary way, but not as a result of the revolutionary changes. Besides, the quality of the formal institutions greatly depends on the quality of the national political system for countries with a revolutionary way of institutions' formation.

3) Statistic observations data for the analysis period.

Thus, the list of countries, which are included in the list considering the above parameters, is presented in Table 1.

We will evaluate the quality of the social sector institutions via the Institutional Quality Index of social sector. The formation of this index is based on the social measures of outcomes without consideration of the economic

Table 1. Grouping of the countries, which are included in the panel data (author's investigation)

\begin{tabular}{|c|c|c|c|c|}
\hline & 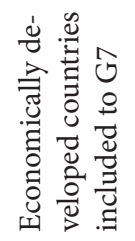 & 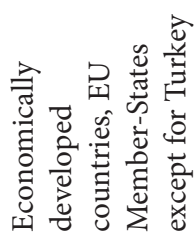 & 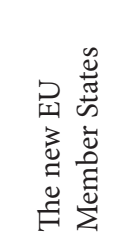 & 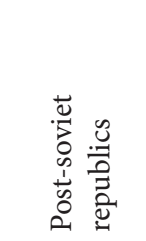 \\
\hline $\begin{array}{l}\text { The evo- } \\
\text { lutionary } \\
\text { way of the } \\
\text { institu- } \\
\text { tions' } \\
\text { establish- } \\
\text { ment }\end{array}$ & $\begin{array}{l}\text { France, } \\
\text { Italy } \\
\text { United } \\
\text { Kingdom }\end{array}$ & $\begin{array}{l}\text { Austria } \\
\text { Belgium } \\
\text { Denmark } \\
\text { Finland } \\
\text { Netherlands } \\
\text { Portugal } \\
\text { Sweden } \\
\text { Turkey }\end{array}$ & & \\
\hline $\begin{array}{l}\text { A revo- } \\
\text { lutionary } \\
\text { way of in- } \\
\text { stitutions' } \\
\text { establish- } \\
\text { ment }\end{array}$ & & & $\begin{array}{l}\text { Czech } \\
\text { Republic } \\
\text { Estonia } \\
\text { Latvia } \\
\text { Lithuania } \\
\text { Romania }\end{array}$ & $\begin{array}{l}\text { Armenia } \\
\text { Georgia } \\
\text { Russian } \\
\text { Federation } \\
\text { Ukraine }\end{array}$ \\
\hline
\end{tabular}


indicators of costs and social expenditures. This indicator is multidimensional. This index includes 20 indicators of the social sector functioning efficiency, which are united into three groups: education, health and social protection. The weighted coefficients of each indicator is defined through the Principal component analysis. The implementation of these official statistic observations in the index formation increases the objectivity of evaluation in comparison with other indicators, which are based on the expert evaluations.

The evaluation of basic institutions' quality is one of the key problems in the study of their establishment and transformation interconnections with economic development on the whole or separate constituents of the social and economic systems. Studying the institutional development researchers have formed and have used many indexes. Some of them are classified as objective indexes and provide the evaluation of the political institutions' quality through Measures of Political Instability and Violence. These indicators were built on the basis of various political occurrences (demonstrations, crimes, strikes, etc). Since there were no alternatives, they were tried to be used for approximation to other institutions' evaluation, that caused the assessments shift (Williams and Siddique 2008).

The second group is considered as the subjective indexes, which are based on the aggregated evaluations of the national experts and surveys. Freedom House Index of Civil and Political Liberties, International Country Risk Guide (ICRG), Business Environment Risk Intelligence (BERI) are the most popular indices, used in the researches. While forming these indices, some aspects of countries' social and economic and political development such as the rule of law, the corruption level or its acceptance level, bureaucracy were evaluated. The key problem consists in the fact that they were not developed with the purpose to analyse institutions, and there is criticism regarding the methodology of their construction (Williams and Siddique 2008).

Recently, the composite indexes have become popular. They combine a lot of indicators, obtained from different bases, that reduces the aggregation mistakes to the global index. Transparency International (TI), and the World Bank's Governance Indicators are the most popular today. The Worldwide Governance Indicators (WGI) by Kaufmann is the most appropriate for our aims. Its creation is aimed at evaluation of the governance, which consists of the traditions and institutions by which authority in a country is exercised (Kaufmann et al. 2010).

The methodology of its formation provides six dimensions of the institutional quality that enables to define the connection and the impact of every dimension on the institutional quality of the social sector. Thus, we will construct six regressions, where every constituent WGI (Voice and Accountability, Political Stability and Absence of Violence/ Terrorism, Government Effectiveness, Regulatory Quality,
Rule of Law, Control of Corruption) will be the independent variable, in order to research the complementarity of the basic institutions and social institutions.

As control variables, the impact of which is defined, we use the GDP per capita, as the indicator of the countries' economic development and GINI coefficient, which defies the inequality level. The relation between the parameters of social institutions' quality is justified by the correlation coefficients and Institutional Quality Index of the social sector.

The list of indicators, which will be used in the construction of the regression, are given in Table 2.

In order to take into account, the possible fluctuations of indicators in time and the influence of the difference in the countries' social and economic development indicators and way to form the institutions, we will use the time Dummy and Dummy variables regarding the country's group.

Thus, the models, evaluated by us, will be shown in the following way:

IQSS $_{i t}=a+\beta_{1}$ VOICE $_{i t}+\beta_{2}$ GINI $_{i t}+\beta_{3}$ LNGDPPERCAP $_{i t}+$ $\beta_{4} y 2007_{i t}+\beta_{5} y 2008_{i t}+\beta_{6} y 2009_{i t}+\beta_{7} y 2010_{i t}+$

$\beta_{8} y 2011_{i t}+\beta_{9} y 2012_{i t}+\beta_{10} y 2013_{i t}+\beta_{11} c 1_{i t}+$

$\beta_{12} c 2_{i t}+\beta_{13} c 3_{i t}+e_{i t}$;

Table 2. Description of the regression variables (source: authors' compilation)

\begin{tabular}{|l|l|l|}
\hline \multicolumn{1}{|c|}{ Variable } & Type of Variable & \multicolumn{1}{|c|}{ Designation } \\
\hline $\begin{array}{l}\text { Institutional Quality } \\
\text { Index of social sector }\end{array}$ & Dependent & IQSS \\
\hline Voice and Accountability & Independent 1 & VOICE \\
\hline $\begin{array}{l}\text { Political Stability and } \\
\text { Absence of Violence/ } \\
\text { Terrorism }\end{array}$ & Independent 2 & POLSTAB \\
\hline $\begin{array}{l}\text { Government } \\
\text { Effectiveness }\end{array}$ & Independent 3 & GOVEFFEC \\
\hline Regulatory Quality & Independent 4 & REGQUAL \\
\hline Rule of Law & Independent 5 & RULE OF LAW \\
\hline Control of Corruption & Independent 6 & CORRUPT \\
\hline GINI Index & Control & GINI \\
\hline Gross Domestic Product & Control & GDPPERCAP \\
\hline Year dummy 2007 & Dummy & y2007 \\
\hline Year dummy 2008 & Dummy & y2008 \\
\hline Year dummy 2009 & Dummy & y2009 \\
\hline Year dummy 2010 & Dummy & y2010 \\
\hline Year dummy 2011 & Dummy & y2011 \\
\hline Year dummy 2012 & Dummy & y2012 \\
\hline Year dummy 2013 & Dummy & y2013 \\
\hline Country dummy 1 & Dummy & c1 \\
\hline Country dummy 2 & Dummy & c2 \\
\hline Country dummy 3 & Dummy & c3 \\
\hline
\end{tabular}




$$
\begin{aligned}
& I_{Q S S} S_{i t}=a+\beta_{1} P_{O L S T A B}+\beta_{2} G_{i N I}+\beta_{3} L N G D P P E R C A P_{i t}+ \\
& \beta_{4} y 2007_{i t}+\beta_{5} y 2008_{i t}+\beta_{6} y 2009_{i t}+\beta_{7} y 2010_{i t}+ \\
& \beta_{8} y 2011_{i t}+\beta_{9} y 2012_{i t}+\beta_{10} y 2013_{i t}+\beta_{11} c 1_{i t}+ \\
& \beta_{12} c 2_{i t}+\beta_{13} c 3_{i t}+e_{i t} \text {; } \\
& \text { IQSS }_{i t}=a+\beta_{1} \text { GOVEFFEC }_{i t}+\beta_{2} \text { GINI }_{i t}+\beta_{3} \text { LNGDPPERCAP }_{i t}+ \\
& \beta_{4} y 2007_{i t}+\beta_{5} y 2008_{i t}+\beta_{6} y 2009_{i t}+\beta_{7} y 2010_{i t}+ \\
& \beta_{8} y 2011_{i t}+\beta_{9} y 2012_{i t}+\beta_{10} y 2013_{i t}+\beta_{11} c 1_{i t}+ \\
& \beta_{12} c 2_{i t}+\beta_{13} c 3_{i t}+e_{i t} \text {; }
\end{aligned}
$$

\section{Results}

The analysis of the descriptive statistics confirms the data uniformity. The correlation values checking did not reveal multicollinearity of independent variables (maximum value was -0.76 - correlation between indicators Institutional Quality Index of the social sector and GINI Index). Besides, the correlation analysis confirms reasonability GINI Index and Gross Domestic Product to be included into the regression as control variables (Figure 1). As we can see from the figure, only 7 of 20 countries have the correlation between
Institutional Quality Index of the social sector and GINI Index less than $30 \%$. The direct and indirect connection between indicators is peculiar for every group, therefore the selected countries shared equally. The calculated correlation coefficient by all countries (cross-country) on the data of 2014 is $(-0.764)$. This value is similar to the obtained results (Chong and Gradstein 2007). In their work authors defined the essential correlation between indicators of the institutional quality and inequality level and identified the direct dependence between the institutions' weakness level and inequality in the country.

The program STATA 13.0 helps us to evaluate the independent, control and Dummy variables. As a result, every of six regressions was evaluated through three models Pooled OLS estimator, Random effects estimator, Fixed effects or within estimator (Appendix 1,2).

The selection of the adequate model is based on the Breusch and Pagan Lagrangian multiplier test for random effects and Hausman test for fixed versus random effects model, the results are shown in the Table 3.

On the next stage we will analyse the fitting of the model and statistical significance of the obtained evaluations.

Fixed effect models, selected as the most appropriate models to check the dependence of the social institutions' quality on the following governance dimensions Control of Corruption, Political Stability and Absence of Violence, Voice and Accountability, showed the low quality of the fitting. The determination coefficients (R2) of the models are $0.114,0.111,0.115$ respectively. It means that only $11 \%$ of the Institutional Quality Index of social sector variation may be explained by the independent variables. Most of the variation accounts for the individual effects for countries (rho is approximately 0,98), however, the correlation between individual effects and regressors is low.

For purpose to estimate the Regulatory Quality the statistical significance could be $\mathrm{p}<10 \%$. The random effect which was defined as the most adequate to check

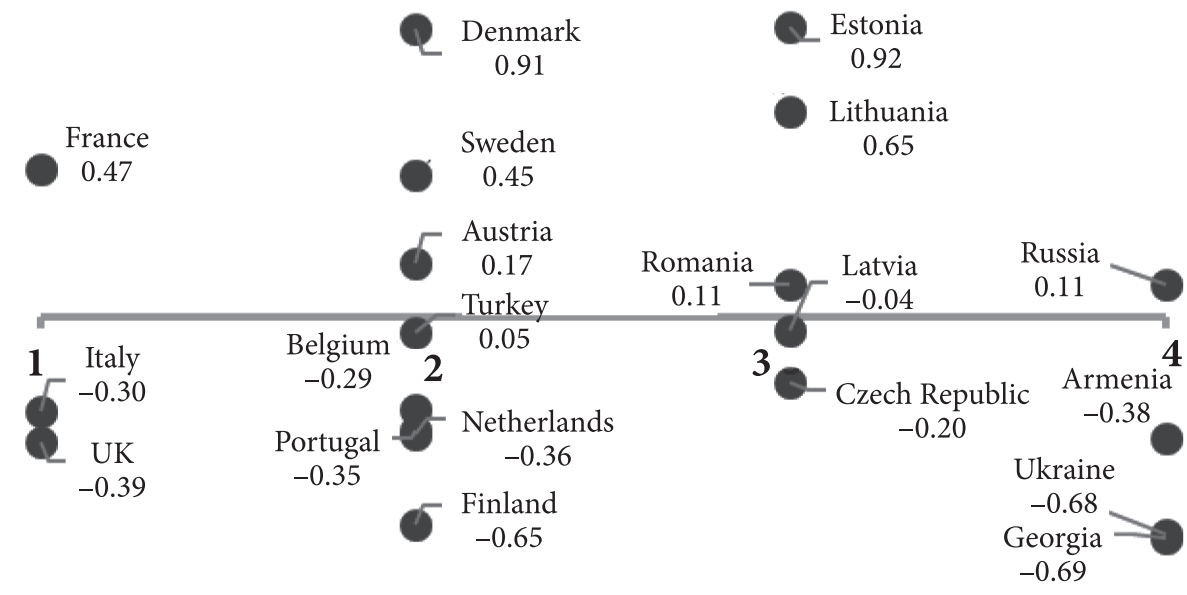

Figure 1. The correlation coefficients between the Institutional Quality Index of the social sector and GINI Index (source: authors' calculation) 
Table 3. Selection of the adequate model through the Breusch and Pagan Lagrangian and Hausman tests (source: authors' calculation)

\begin{tabular}{|l|l|l|l|l|l|l|}
\hline \multicolumn{1}{|c|}{ Test } & \multicolumn{1}{|c|}{$\begin{array}{c}\text { Voice and } \\
\text { Accountability }\end{array}$} & $\begin{array}{c}\text { Political Stability } \\
\text { and Absence of } \\
\text { Violence }\end{array}$ & $\begin{array}{c}\text { Government } \\
\text { Effectiveness }\end{array}$ & $\begin{array}{c}\text { Regulatory } \\
\text { Quality }\end{array}$ & \multicolumn{1}{c|}{$\begin{array}{c}\text { Rule of Law } \\
\text { Corruption }\end{array}$} \\
\hline $\begin{array}{l}\text { Breusch-Pagan LM test for } \\
\text { random effects versus OLS } \\
\text { Null hypothesis }\end{array}$ & rejected & rejected & rejected & rejected & rejected & rejected \\
\hline $\begin{array}{l}\text { Hausman test for fixed ver- } \\
\text { Null hypothesis }\end{array}$ & rejected & rejected & not rejected & rejected & not rejected & rejected \\
\hline Model chosen & Fixed effect & Fixed effect & Random effects & Fixed effect & Random effects & Fixed effect \\
\hline
\end{tabular}

the dependence of the social institutions' quality on the following dimensions of the governance - Government Effectiveness and Rule of Law. The model's quality is evaluated not by the determination coefficients but based on the Wald test. The obtained values of the Wald chi2 prove the normal quality of the models. The requirement regarding the absence of the correlation between individual random effects and regressors is fulfilled.

\section{Conclusions}

Is the question regarding the quality of institutions of the social sector debatable today? Besides, the analysing of the social sector as a part of the market economy is an anomaly if you understand it from the position of classical economic theory. However, today, at the transnational level European Social Charter, which as an institution forms path dependence regarding the economic development of the most European countries, is acting. It means that nowadays, there is a social framework, in relation to which the economic institutions are formed. That is why, studying the quality of the social institutions, we put the question: does this quality depends on the basic institutions, representing them via six key dimensions of Governance: "Voice and Accountability", "Political Stability", "Government Effectiveness", "Regulatory Quality", "Rule of Law" "Control of Corruption", i.e., is there the institutional complementarity between institutions of this type?

According to results of the panel data analysis, it has been defined that the impact on the institutional quality "Voice and Accountability", "Political Stability" and "Control of Corruption" is not statistically significant. Such results regarding the first two dimensions of Governance are clear in general because the analysed countries demonstrate the already formed social standards system, which does not depend on the citizens' possibility to select the government or political destabilization. So, the institutions of the social sector are stable in relation to the political instability or the citizens' freedoms oppressions (freedom of media, freedom of association, freedom of expression). As for the "Control of Corruption", the absence of the influence may be explained, firstly, by the IQSS structure (indicators, included in its structure, are not "sensitive" to the corruption), secondly, this indicator is reasonable to be analysed by the Rule of Law, since the trusting degree to the determined rules, including the judicial authorities, police etc, is defined by this indicator.

Among all regulation dimensions "Rule of Law" and "Regulatory Quality" reveal the statistically significant direct impact on the IQSS. It may confirm the complementarity of basic institutions and institutions of the social sector. The trusting level to the law, its following and quality of the social sector, the ability of the government to provide sound policy and regulation that enables to promote private sector development is a representative constituent of institutions, including the economic ones, which form the institutional base.

The results of the evaluation by the indicator Government Effectiveness were quite controversial since this indicator does not have a statistically significant impact on the social institutional quality. The GINI coefficient and GDP per capita, included in the analysis of these variables, are significant. It may justify that Government Effectiveness indicator also is a result of the incomes distribution inequality impact and general economic welfare. It is necessary to carry out additional studies of the above parameters' interconnection for more fundamental conclusions.

Let us notice that all conclusions are fair for four groups of countries.

We understand the limitation of the proposed methodology to evaluate the institutional complementarity. In the approach, which we propose, the informal institutions are out of the analysis, although they may have great influence on the development of the social sector. Besides, our research is oriented to find the one-way connection of the regulatory institutions and social institutions' quality, although more profound analysis of the complementarity requires the two-way communication evaluation. Although the problem of the complementarity dimension is complicated, especially when it concerns the social sector, Deeg (2005: 5) points out that "selecting performance criteria 
also grows more challenging when the complementarity of interest is social (e.g, trust, cooperation) or political (e.g., power) in nature. It may also be that our ability to measure complementarities will, in the end, be of a rather crude nature and thus we will, at best, only be able to ascertain with some certainty whether some kind of complementarity exists or does not".

We suppose that the obtained results in the research could be used in the determination of the key points in the implementation of the reforms. Since the problem regarding institutions' development is more urgent for the developing and transition countries than for the developed countries, it is reasonable to perform more detailed analysis of the institutions' complementarity for countries, included to the $3 \mathrm{~d}$ and $4^{\text {th }}$ groups by us. The complementarity as a factor of the institutional quality is important for the economic policy, since the institutional changes, which have been already introduced or are planned to be implemented in the social sector, may be inappropriate with the current institutional structure and will not give the expected results.

\section{Acknowledgements}

This research was funded by the grant from the Ministry of Education and Science of Ukraine (№ g/r 0118U003569).

\section{References}

Acemoglu D, Johnson S, Robinson JA (2005) Institutions as a Fundamental Cause of Long-Run Growth. Handbook of Economic Growth 1A: 386-472. Elsevier.

Acemoglu D, Johnson S (2005) Unbundling institutions. Journal of Political Economy 113 (5): 949-995. https://doi. org/10.1086/432166

Amable B (2016) Institutional complementarities in the dynamic comparative analysis of capitalism. Journal of Institutional Economics 12 (1): 79-103 https://www.cambridge.org/core/ services/aop-cambridge-core/content/view/8ED45248B6 309CA1FB8504CA48E05F9D/S1744137415000211a.pdf/ institutional_complementarities_in_the_dynamic_comparative_analysis_of_capitalism.pdf

Bagmet KV, Haponova O (2018) Assessing the impact on social sector: A macroeconomic approach. SocioEconomic Challenges 3 (2): 103-108. https://doi.org/10.21272/sec.3(2).103108.2018

Bartlett W, Cǔ̌koviă N, Jurlin K, Nojkoviă A, Popovski V (2013) Institutional quality and growth in EU neighbourhood countries. WP5/11 Search Working Paper http://www.ub.edu/ searchproject/wp-content/uploads/2013/01/WP-5.11.pdf

Boyer R (2005) Coherence, diversity, and the evolution of capitalisms - the institutional complementarity hypothesis. Evolutionary and Institutional Economics Review 2 (1): 4380. https://doi.org/10.14441/eier.2.43

Boyer R (2007) Growth strategies and poverty reduction: the institutional complementarity hypothesis. PSE Working Papers $n^{\circ} 2007-43$ https://halshs.archives-ouvertes.fr/ halshs-00587703/document
Bruinshoofd A (2016) Institutional quality and economic performance. Retrieved from https://economics.rabobank. com/publications/2016/january/institutional-quality-andeconomic-performance/

Cavalcanti T, Novo Á (2005) Institutions and economic development: How strong is the relation? Empirical Economics 30: 263. https://doi.org/10.1007/s00181-004-0217-5

Chong A, Gradstein M (2007) Inequality and institutions. The Review of Economics and Statistics 89 (3): 454-465. https:// doi.org/10.1162/rest.89.3.454

Chousa J, Khan H, Melikyan D, Tamazian A (2005) Assessing institutional efficiency, growth and integration. Emerging Markets Review 6: 69-84. https://doi.org/10.1016/j.ememar.2004.09.004

Deeg R (2005) Complementarity and institutional change: How useful a concept? Discussion Paper SP II 2005 - 21, Wissenschaftszentrum, Berlin https://bibliothek.wzb.eu/pdf/2005/ ii05-21.pdf

Dkhili H (2018) Environmental performance and institutions quality: evidence from developed and developing countries. Marketing and management of innovations (3): 333-344. https://doi.org/10.21272/mmi.2018.3-30

Draskovi V, Popov E, Peleckis KK (2017) Modelling of institutional changes in transition countries - the gap between the theory and practice. Montenegrin Journal of Economics 13 (1): 121-140. https://doi.org/10.14254/1800-5845/2017.131.9

Draskovic M, Milica D, Mladen I, Chigisheva O (2017) Preference of institutional changes in social and economic development. Journal of International Studies 10 (2): 318-328. https://doi. org/10.14254/2071-8330.2017/10-2/22

Efendica A, Pugh G (2015) Institutional effects on economic performance in transition: a Dynamic Panel Analysis. Acta Oeconomica https://www.researchgate.net/profile/Adnan_ Efendic2/publication/268977486_Institutional_effects_on economic_performance_in_post-socialist_transition_a_dynamic_panel_analysis/links/547c2ec00cf205d16881d588/ Institutional-effects-on-economic-performance-in-postsocialist-transition-a-dynamic-panel-analysis.pdf

Efendica A, Pughb G, Adnettb N (2010) Institutions and economic performance: System GMM modelling of institutional effects in transition http://www.efsa.unsa.ba/ adnan.efendic/materijali/Efendic\%20et\%20al.\%202010\%20INSTITUTIONS\%20IN\%20TRANSITION.pdf

Eicher T, Schreiber T (2010) Structural policies and growth: time series evidence from a natural experiment. Journal of Development Economics 91 (2010): 169-179. https://doi.org/ 10.1016/j.jdeveco.2009.05.003

Elert N, Halvarsson D (2012) Economic freedom and institutional convergence. Ratio Working Paper No. 196, November 27, 2012 http://ratio.se/app/uploads/2014/11/ne_dh_-working paper_200_elert_trippleh.pdf

Hájek Ja, Hoeschle F, Bilan Yu, Strielkowski W (2016) Economic performance and convergence in the Eurozone. Marketing and Management of Innovations 1: 206-223.

Hall JC (2015) Institutional convergence: Exit or voice? West Virginia University. September 2015 http://busecon.wvu.edu/ phd_economics/pdf/15-40.pdf 
Harold, N Ng Yan (2018) Econometric analysis of long and shortrun effects of exports on economic growth in Cameroon (1980-2016). Financial Markets, Institutions and Risks 2 (1): 50-57. https://doi.org/10.21272/fmir.2(1).50-57.2018

Harshad D (2017a) An inquiry on social issues - Part 1. Business Ethics and Leadership 1 (2): 78-87.

Harshad D (2017b) An inquiry on social issues - Part 2. Business Ethics and Leadership 1 (3): 45-63. https://doi.org/10.21272/ bel.1(3).45-63.2017

IMF (2005) World Economic Outlook, September 2005: Chapter 3. Building. Institutions - IMF https://www.imf.org/en/ Publications/WEO/Issues/2016/12/31/World-EconomicOutlook-September-2005-Building-Institutions-18303

Jayasundera M (2017) Ancient Sri Lankan Economic Systems. Financial Markets, Institutions and Risks 1 (4): 24-27. https:// doi.org/10.21272/fmir.1(4).24-27.2017

Jovovic R, Draskovic M, Delibasic M, Jovovic M (2017) The concept of sustainable regional development - institutional aspects, policies and prospects. Journal of International Studies 10 (1): 255-266. https://doi.org/10.14254/2071$8330.2017 / 10-1 / 18$

Kaasa A, Kaldaru H, Parts E (2007) Social capital and institutional quality as factors of innovation: Evidence from Europe $\mathrm{ftp}: / /$ ftp.repec.org/opt/ReDIF/RePEc/mtk/febpdf/febawb55.pdf

Kaasa A (2016) Social capital, institutional quality and productivity: Evidence from European Regions. Economics and Sociology 9 (4), 11-26/9-4/1.

Kandil M (2009) Determinants of institutional quality and their impact on economic growth in the MENA region. International Journal of Development Issues 8 (2): 134-167. https:// doi.org/10.1108/14468950910997693

Kaufmann D, Kraay A, Mastruzzi M (2010) The Worldwide Governance Indicators: Methodology and Analytical Issues. Policy Research working paper; no. WPS 5430. World Bank. (C) World Bank https://openknowledge.worldbank.org/ handle/10986/3913 License: CC BY 3.0 IGO

Iqbal K (2018) Human development and economic growth in Pakistan. SocioEconomic Challenges 3 (2): 66-75. https:// doi.org/10.21272/sec.3(2).66-75.2018

Kostel M, Leus D, Cebotarenco A, Mokrushina A (2017) The sustainable development goals for Eastern partnership countries: Impact of institutions. SocioEconomic Challenges 1 (3): 79-90. https://doi.org/10.21272/sec.1(3).79-90.2017

Kyrychenko K, Samusevych Y, Liulova L, Bagmet K (2018) Innovations in country's social development level estimation. Marketing and management of innovations (2): 113-128. https://doi.org/10.21272/mmi.2018.2-10

Logan W, Esmanov O (2017) Public financial services transparency. Business Ethics and Leadership 1 (2): 62-67. https://doi. org/10.21272/bel.1(2).62-67.2017

Lunyakov OV, Vasilyeva TA, Leonov SV (2013) Analysis of internal and external imbalances in the financial sector of Ukraine's economy. Actual Problems of Economics 12 (150): 176-184.

Melnyk L, Sineviciene L, Lyulyov O, Pimonenko T, Dehtyarova I (2018) Fiscal decentralization and macroeconomic stability: The experience of Ukraine's economy. Problems and Perspectives in Management 16 (1): 105-114. https://doi. org/10.21511/ppm.16(1).2018.10
Pagano U (2011) Interlocking complementarities and institutional change. Journal of Institutional Economic 7 (3): 373-392. https://doi.org/10.1017/S1744137410000433

Pilia G (2017) Estonia and Lithuania in transition: A compared analysis of the change and its costs and benefits. Business Ethics and Leadership 1 (2): 12-19. https://doi.org/10.21272/ bel.1(2).12-19.2017

Redek T, Susjan A (2005) The impact of institutions on economic growth: The case of transition economies. Journal of Economic Issues XXXIX (4): 995-1027. https://doi.org/10.1080/ 00213624.2005 .11506864

Rivera Rios MA, Lujano Lopez JB, Garcia Veiga J (2018) The fifth global kondratiev. Low economic performance, instability and monopolization in the digital age. Marketing and Management of Innovations (2): 270-291.

Rogowski R (2017) Theoretical reasons for economic sociology. SocioEconomic Challenges 1 (4): 45-49. https://doi. org/10.21272/sec.1(4).45-49.2017

Schönfelder N, Wagner H (2018) Institutional convergence in Europe. Discussion Paper No. 2018-53. July 02, 2018 http://www. economics-ejournal.org/economics/discussionpapers/2018-53

Shvindina H (2017) Leadership as a driver for organizational change. Business Ethics and Leadership 1 (1): 74-82. https:// doi.org/10.21272/bel.2017.1-09

Tamilina L, Tamilina N (2014) Heterogeneity in institutional effects on economic growth: Theory and empirical evidence. European Journal of Comparative Economics 11 (2): 205-249.

Tamilina L, Tamilina N (2017) Post-communist transition as a path break: Comparing legal institutional effects on economic growth between path-breaking and path-drifting institutional reforms. The Journal of Applied Economic Research 11 (3): 315-347. https://doi.org/10.1177/0973801017703513

Valeriani E, Peluso S (2011) The impact of institutional quality on economic growth and development: An Empirical Study. Journal of Knowledge Management, Economics and Information Technology 6.

Vasilyeva T, Lyeonov S, Adamičková I, Bagmet K (2018a) Institutional quality of social sector: the essence and measurements. Economics and Sociology 11 (2): 248-262. https://doi. org/10.14254/2071-789X.2018/11-2/17

Vasylieva T, Lyeonov S, Lyulyov O, Kyrychenko K (2018b) Macroeconomic stability and its impact on the economic growth of the country. Montenegrin Journal of Economics 14 (1): 159-170. https://doi.org/10.14254/1800-5845/2018.14-1.12

Vitola A, Senfelde M (2015) The role of institutions in economic performance. Business: Theory and Practice 16 (3): 271-279. https://doi.org/10.3846/btp.2015.498

WEF (2018) Klaus Schwab, World Economic Forum. The Global Competitiveness Report 2017-2018 http://www3.weforum. org/docs/GCR2017-2018/05FullReport/TheGlobalCompetiti venessReport2017\%E2\%80\%932018.pdf

Williams A, Siddique A (2008) The use (and abuse) of governance indicators in economics: a review. Economics of Governance 9: 131. https://doi.org/10.1007/s10101-006-0025-9

Yevdokimov Y, Melnyk L, Lyulyov O, Panchenko O, Kubatko O (2018) Economic freedom and democracy: Determinant factors in increasing macroeconomic stability. Problems and Perspectives in Management 16 (2): 279-290. https://doi. org/10.21511/ppm.16(2).2018.26 


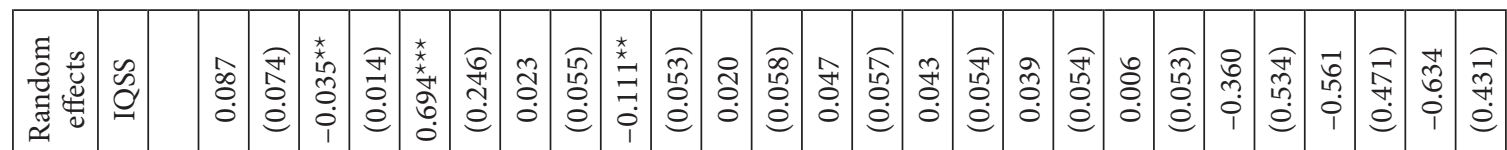

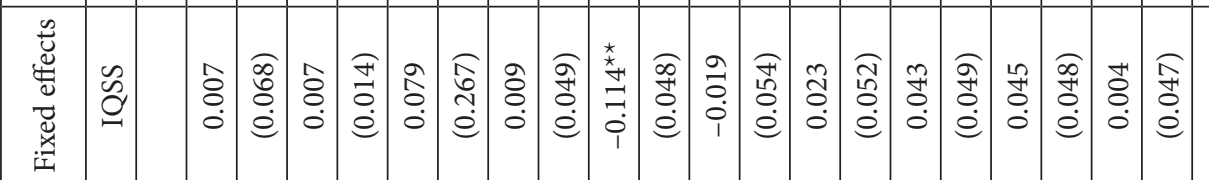

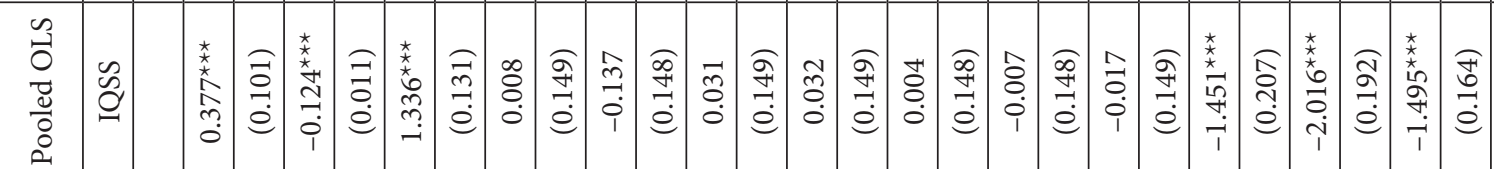

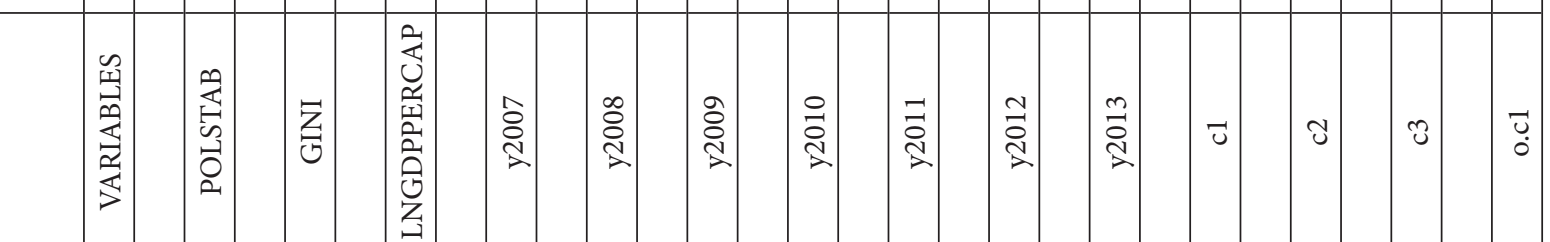

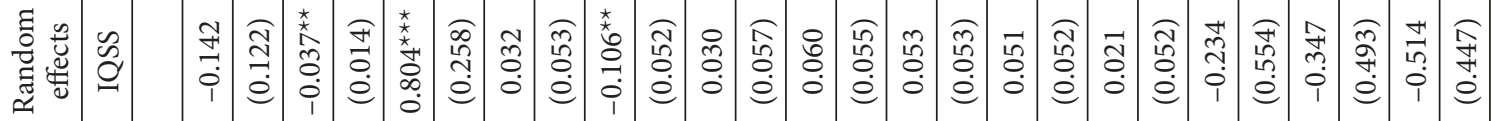

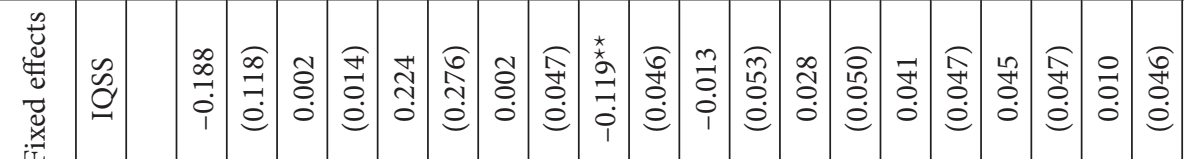

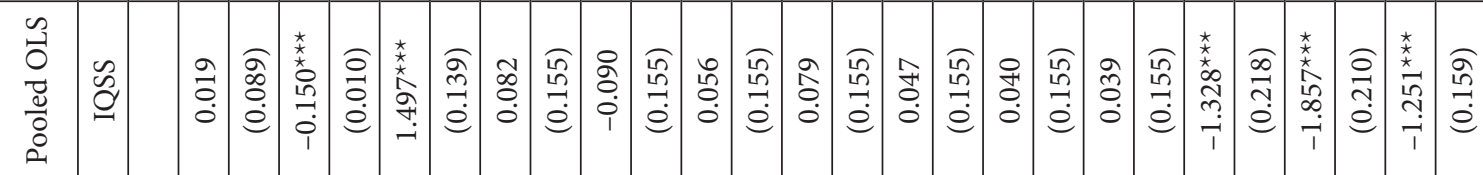

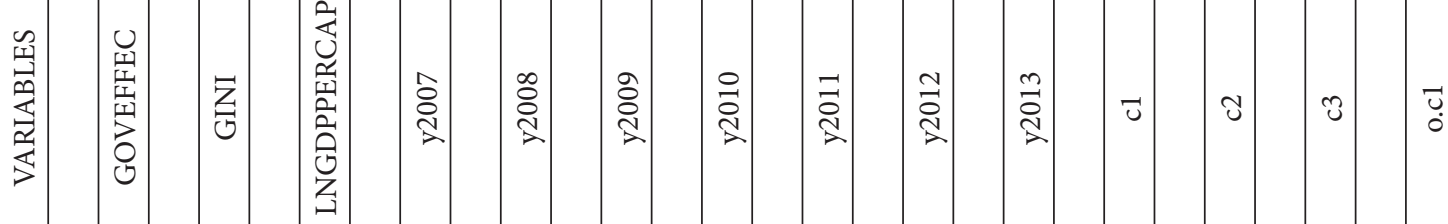

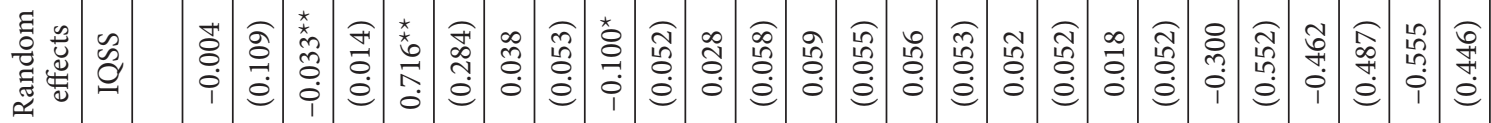

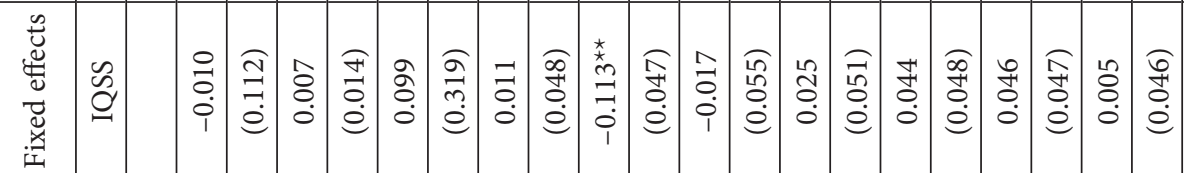

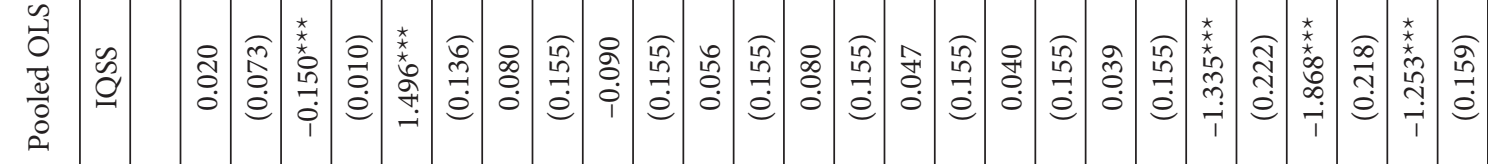

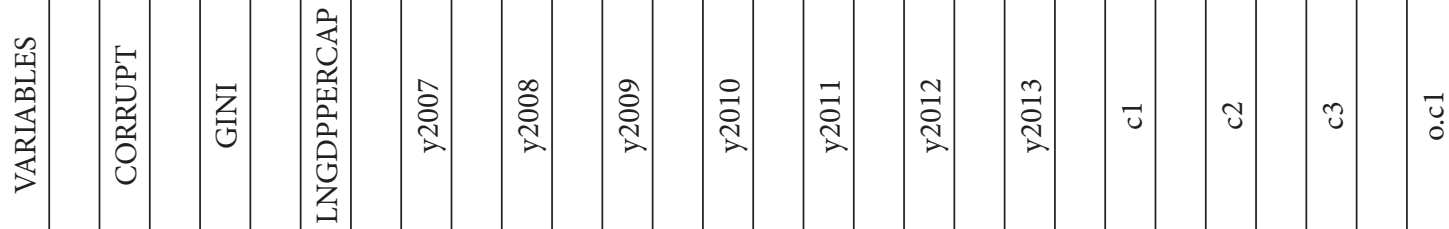




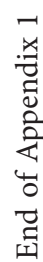

\begin{tabular}{|c|c|c|c|c|c|c|c|c|c|}
\hline 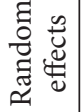 & & & $\begin{array}{c}\infty \\
\infty \\
m \\
0 \\
1 \\
1\end{array}$ & $\begin{array}{l}\stackrel{a}{\vec{g}} \\
\vec{d} \\
\stackrel{d}{d}\end{array}$ & 8 & & $\stackrel{\sim}{\text { I }}$ & & \\
\hline 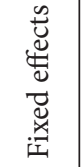 & 1 & 1 & \begin{tabular}{|l|}
2 \\
0 \\
+ \\
+ \\
+
\end{tabular} & 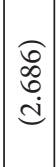 & $\stackrel{8}{0}$ & $\mid \begin{array}{c} \pm \\
\vdots \\
0\end{array}$ & $\stackrel{i}{i}$ & \multirow{3}{*}{ 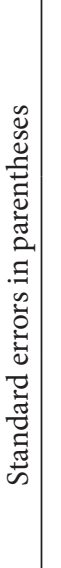 } & \multirow{3}{*}{ 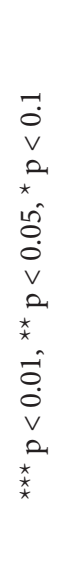 } \\
\hline 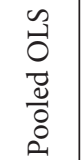 & & & 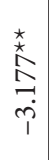 & 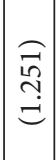 & $\stackrel{8}{\circ}$ & $\mid \begin{array}{c}\forall \\
\infty \\
0 \\
0\end{array}$ & & & \\
\hline & $\stackrel{\widetilde{O}}{\tilde{0}}$ & $\stackrel{3}{0}$ & 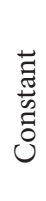 & & 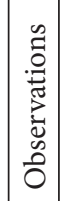 & 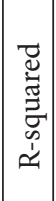 & 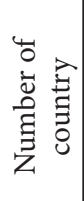 & & \\
\hline & & & & & & & & & \\
\hline 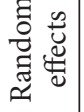 & & & 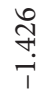 & \begin{tabular}{c|}
$\widehat{a}$ \\
$\stackrel{\infty}{0}$ \\
$\stackrel{d}{d}$
\end{tabular} & $\stackrel{8}{0}$ & & $\stackrel{\sim}{\text { I }}$ & & \\
\hline 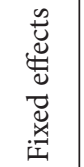 & । & 1 & $\begin{array}{l}\vec{n} \\
\stackrel{i}{n}\end{array}$ & 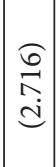 & $\stackrel{8}{0}$ & $\begin{array}{c}\vec{m} \\
\overrightarrow{0}\end{array}$ & 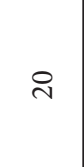 & \multirow{3}{*}{ 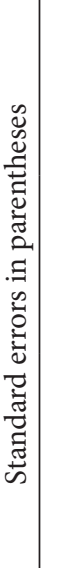 } & \multirow{3}{*}{ 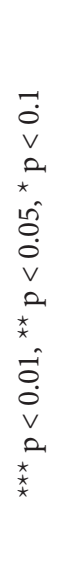 } \\
\hline $\begin{array}{l}\tilde{a} \\
0 \\
0 \\
0 \\
0 \\
0 \\
0\end{array}$ & & & 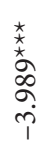 & 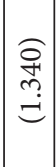 & $\stackrel{8}{0}$ & $\mid \begin{array}{l}2 \\
\grave{2} \\
0\end{array}$ & & & \\
\hline & $\stackrel{\widetilde{U}}{0}$ & $\stackrel{\vartheta}{0}$ & $\begin{array}{l}\text { 䔍 } \\
\text { के } \\
\text { है }\end{array}$ & & 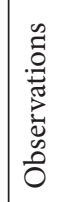 & 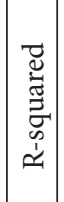 & 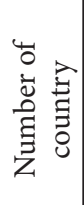 & & \\
\hline 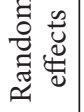 & & & $\begin{array}{l}\stackrel{\infty}{\stackrel{1}{0}} \\
\stackrel{i}{i}\end{array}$ & 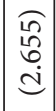 & $\stackrel{0}{0}$ & & $\stackrel{\sim}{\text { I }}$ & & \\
\hline 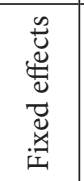 & 1 & I & $\begin{array}{c}\hat{N} \\
\text { o. } \\
\dot{n}\end{array}$ & $\mid$\begin{tabular}{|c}
0 \\
0 \\
0 \\
0 \\
0
\end{tabular} & $\stackrel{8}{0}$ & 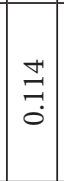 & ㄱ. & & \\
\hline $\begin{array}{l}3 \\
0 \\
0 \\
\frac{0}{0} \\
0 \\
0\end{array}$ & & & 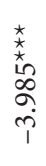 & 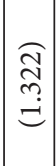 & $\stackrel{8}{0}$ & $\mid \begin{array}{l}2 \\
\grave{2} \\
0\end{array}$ & & 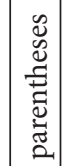 & $\begin{array}{l}v \\
n \\
\star \\
\vdots \\
0 \\
0 \\
0 \\
v\end{array}$ \\
\hline & $\underset{0}{\tilde{0}}$ & $\ddot{0}$ & 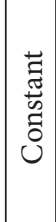 & & 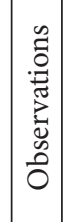 & 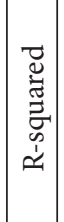 & 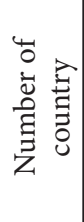 & 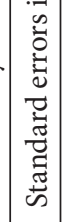 & 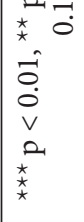 \\
\hline
\end{tabular}




\begin{tabular}{|c|c|c|c|c|c|c|c|c|c|c|c|c|c|c|c|c|c|c|c|c|c|c|c|c|}
\hline 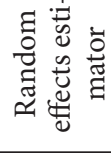 & $\begin{array}{l}\tilde{a} \\
\tilde{a}\end{array}$ & $\begin{array}{l}\vec{\infty} \\
\overrightarrow{0}\end{array}$ & $\begin{array}{l}\text { 递 } \\
\stackrel{0}{0}\end{array}$ & 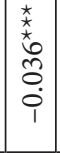 & $\mid \begin{array}{c}\overparen{f} \\
0 \\
\dot{e}\end{array}$ & $\begin{array}{l}\text { t. } \\
\text { t. } \\
\hat{\sigma} \\
0 \\
0 \\
0\end{array}$ & 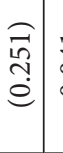 & $\begin{array}{l}\vec{F} \\
\dot{0} \\
\dot{0}\end{array}$ & $\begin{array}{l}\widehat{\tilde{n}} \\
0 \\
\dot{e}\end{array}$ & 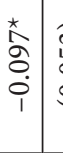 & 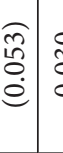 & \begin{tabular}{l|l}
0 & $\infty$ \\
0 & \\
0 & 0 \\
0 & 0
\end{tabular} & $\begin{array}{l}0 \\
\vdots \\
\dot{c} \\
\dot{c}\end{array}$ & $\mid \begin{array}{l}0 \\
b \\
o \\
\stackrel{0}{e}\end{array}$ & $\mid \begin{array}{l}0 \\
\ddot{0} \\
\dot{0}\end{array}$ & $\begin{array}{l}\text { f } \\
\text { d } \\
\dot{e}\end{array}$ & \begin{tabular}{l|l}
\multirow{2}{0}{} \\
$\stackrel{0}{0}$
\end{tabular} & 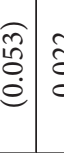 & 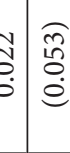 & $\begin{array}{l}\infty \\
0 \\
10 \\
0 \\
1\end{array}$ & 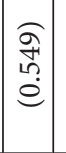 & 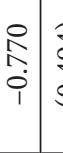 & 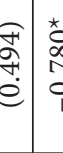 & \\
\hline 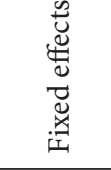 & $\begin{array}{l}\mathscr{a} \\
\stackrel{a}{a}\end{array}$ & $\begin{array}{c}\hat{1} \\
\stackrel{0}{0} \\
i\end{array}$ & $\begin{array}{l}\hat{\sigma} \\
\stackrel{6}{e}\end{array}$ & $\begin{array}{l}\infty \\
0 \\
0 \\
0\end{array}$ & $\mid \begin{array}{l}\overrightarrow{\vec{f}} \\
\dot{0} \\
\dot{\theta}\end{array}$ & $\begin{array}{l}\hat{n} \\
\stackrel{0}{0} \\
0\end{array}$ & 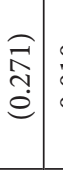 & $\begin{array}{l}0 \\
0 \\
0 \\
0\end{array}$ & $\begin{array}{l}\text { fy } \\
\text { d } \\
\dot{e}\end{array}$ & 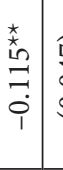 & \begin{tabular}{l|l}
$\frac{1}{5}$ & \\
$\vdots$ & \\
$e$ & \\
$e$ &
\end{tabular} & $\begin{array}{lll}n & 0 \\
0 & 2 \\
0 & 0 \\
1 & 0\end{array}$ & 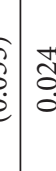 & 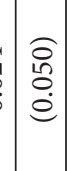 & $\vec{F}$ & $\begin{array}{l}\text { क्षे } \\
\text { ¿े } \\
\dot{e}\end{array}$ & $\begin{array}{l}2 \\
+ \\
0 \\
0 \\
0\end{array}$ & $\begin{array}{c}\text { Fy } \\
\text { o. } \\
\dot{e}\end{array}$ & 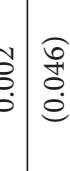 & & & & & \\
\hline 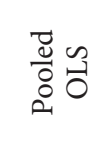 & $\begin{array}{l}\tilde{a} \\
\stackrel{a}{2}\end{array}$ & 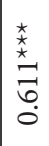 & 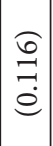 & $\begin{array}{l}\underset{x}{x} \\
6 \\
= \\
0 \\
i \\
1\end{array}$ & $\mid \begin{array}{c}0 \\
0 \\
0 \\
\stackrel{0}{0}\end{array}$ & 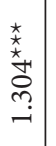 & 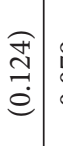 & 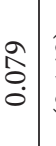 & 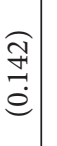 & $\begin{array}{l}0 \\
\infty \\
0 \\
i \\
i\end{array}$ & \begin{tabular}{c|c}
$\stackrel{\Im}{\Im}$ \\
$\stackrel{e}{e}$
\end{tabular} & 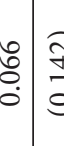 & $\stackrel{\infty}{0}$ & 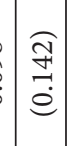 & $\mid \begin{array}{c}N \\
\hat{O} \\
0 \\
0\end{array}$ & $\begin{array}{l}\widehat{I} \\
\stackrel{f}{e}\end{array}$ & 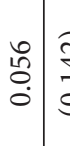 & 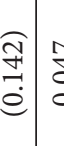 & 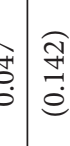 & 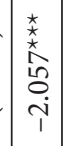 & 吕 & 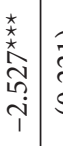 & 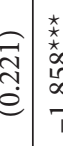 & \\
\hline & 焉 & 岁 & & $\vec{z}$ & & 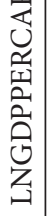 & & 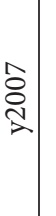 & & 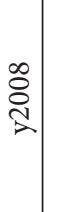 & & ठ્ટે & 更 & & $\begin{array}{l}\overrightarrow{0} \\
\bar{N}\end{array}$ & & $\begin{array}{l}\tilde{I} \\
\stackrel{D}{\lambda}\end{array}$ & $\Xi$ & $\begin{array}{c}2 \\
2 \\
\end{array}$ & $\bar{u}$ & & U & 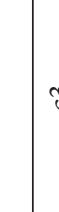 & \\
\hline
\end{tabular}

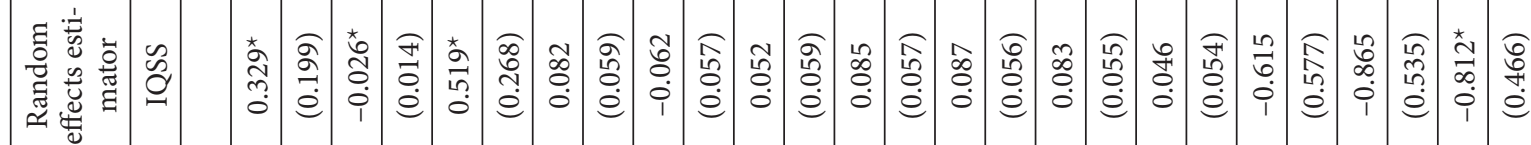

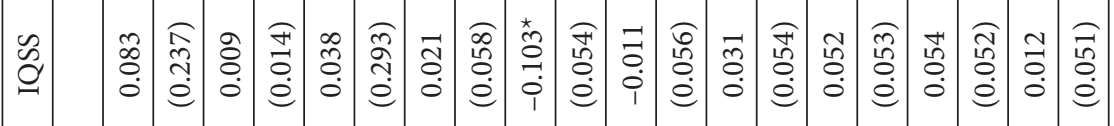

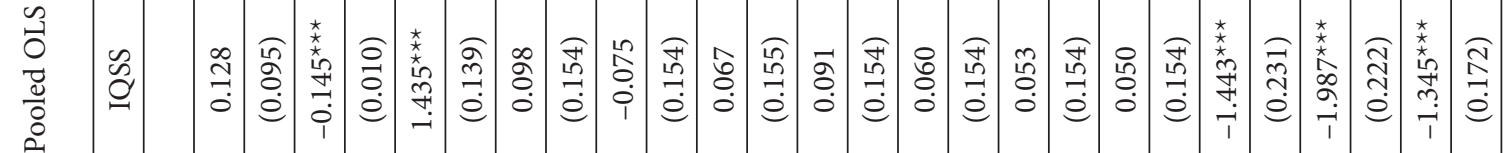

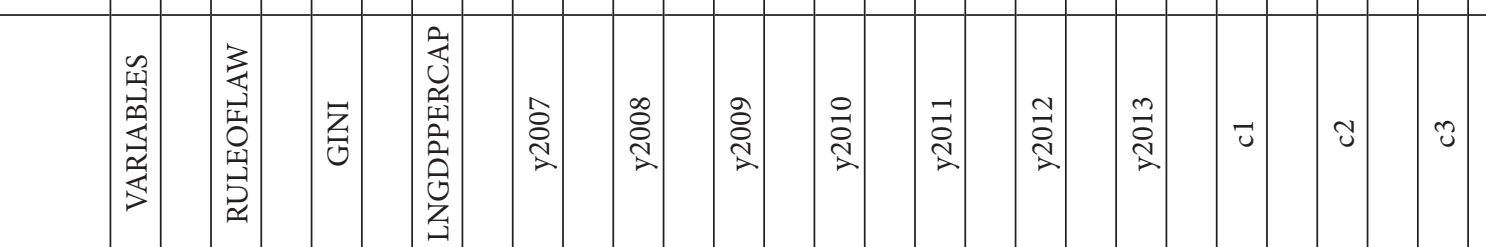

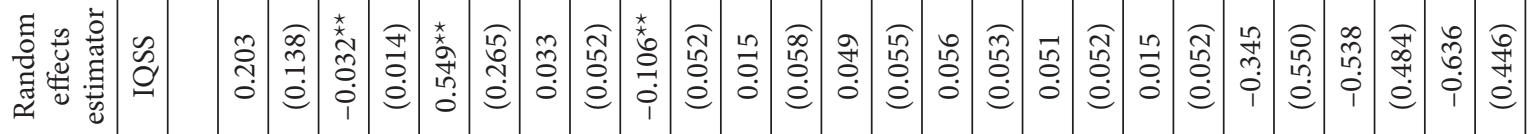

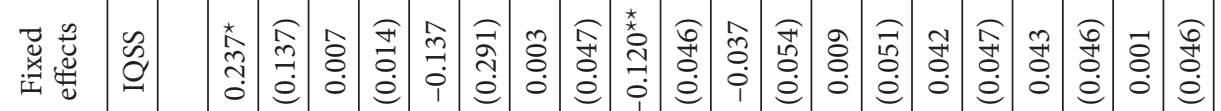

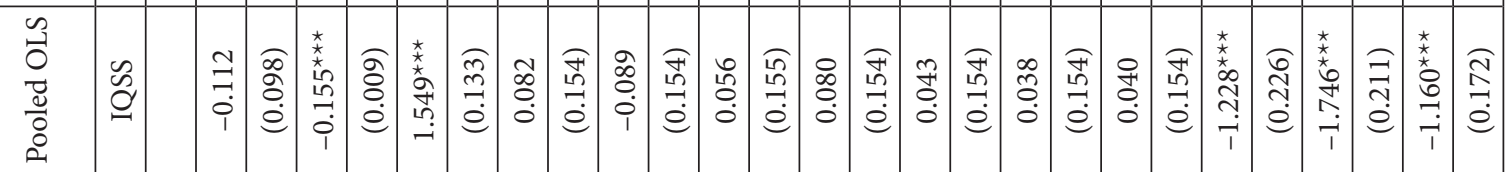
岱 


\begin{tabular}{|c|c|c|c|c|c|c|c|c|c|c|}
\hline 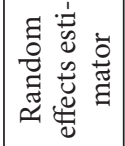 & & & & $\begin{array}{l}n \\
\hat{n} \\
0 \\
0 \\
1\end{array}$ & 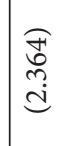 & $\stackrel{8}{0}$ & & సి & & \\
\hline 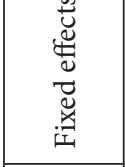 & 1 & 1 & 1 & $\begin{array}{l}a \\
\dot{+} \\
\dot{m}\end{array}$ & $\begin{array}{l}\widehat{̊} \\
\stackrel{d}{d} \\
\text { d. }\end{array}$ & $\stackrel{8}{-}$ & 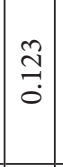 & ㄱ. & \multirow{3}{*}{\multicolumn{2}{|c|}{ 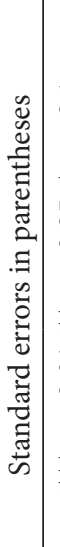 }} \\
\hline $\begin{array}{l}\overrightarrow{0} \\
\ddot{0} \\
0 \\
0\end{array}$ & & & & \begin{tabular}{l}
$x$ \\
\multirow{x}{*}{} \\
0 \\
0 \\
$\dot{p}$ \\
1
\end{tabular} & & $\stackrel{8}{-}$ & $\left|\begin{array}{c}\infty \\
0 \\
0 \\
0 \\
0\end{array}\right|$ & & & \\
\hline & $\stackrel{\breve{0}}{0}$ & U. & S. & 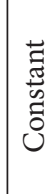 & & 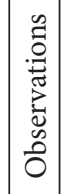 & 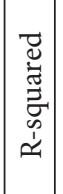 & 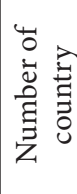 & & \\
\hline
\end{tabular}

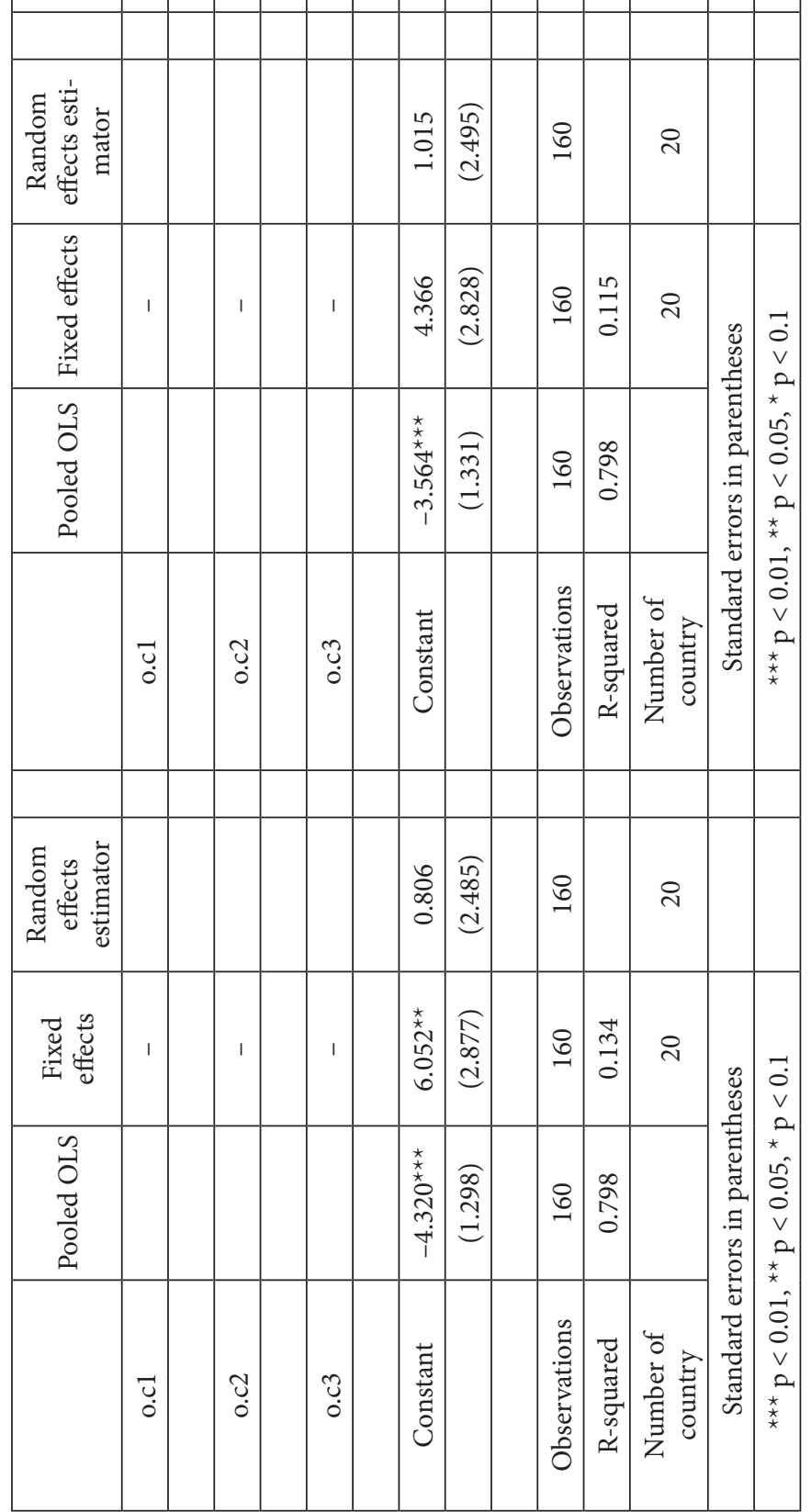

